\title{
STATE OF KNOWLEDGE ABOUT LOW BACK PAIN ASSOCIATED WITH OVERLOAD
}

\section{STAN WIEDZY BADANYCH W ZAKRESIE DOLEGLIWOŚCI BÓLOWYCH KRĘGOSŁUPA NA TLE PRZECIĄŻENIOWYM}

\author{
Academy of Physical Education in Wrocław
}

Su m m a r y

Introduction. Low back pain have become a global problem that is still increasing in our society. It has become epidemic. Unfortunately, it affects young people more often than years ago. Therefore, we cannot underestimate the threat. The main cause is inappropriate and incorrect body position, which places an additional load, external or long-term performance of repetitive charges spine. Both people performing work in a sitting position and standing position are exposed to low back pain.

Target. Aim of the research was to assess state of knowledge about low back pain associated with overload of truck drivers.

Materials and methods. Study group included 120 randomly selected truck drivers from international transport companies from the area of Lower Silesia. The age ranged 25-45 years. Drivers spend at least 9 hours a day behind the wheel. During the study a questionnaire consisting of fifteen questions was used. Grouped questions concerned the extent of knowledge of the respondents about the symptoms of back pain against the overload. All calculations were performed in Microsoft Excel using an average and percentage.

Conclusions. It is important to inform the public about the importance of physical activity, the popularization of active rest and dissemination of prevention and consequences of pathological changes in the field of back pain against overload.

\section{Streszczenie}

W s tę p. Zespoły bólowe kręgosłupa stały się globalnym problemem, który stale się powiększa. Obecnie jest epidemią. Znacznie częściej dotyka młodych ludzi, dlatego nie możemy bagatelizować zagrożenia. Główną przyczyną jest nieodpowiednia i niewłaściwa pozycja ciala, która $\mathrm{z}$ dodatkowym obciążeniem, zewnętrznym bądź długotrwałym wykonywaniem powtarzających się czynności obciąża kręgosłup. Zarówno osoby wykonujące pracę w pozycji siedzącej, jak i stojącej są narażone na bóle kręgosłupa.

Celem pracy jest ocena stanu wiedzy kierowców samochodów ciężarowych w zakresie dolegliwości bólowych kręgosłupa na tle przeciążeniowym oraz profilaktyki następstw zmian o charakterze patologicznym.

Materiał i metody. Grupa ankietowanych liczy 120 losowo wyłonionych kierowców samochodów ciężaro- wych z międzynarodowych firm transportowych z terenu Dolnego Śląska. Przedział wieku wybranych mężczyzn obejmuje 25-45 lat. Służbowo kierowcy spędzają co najmniej 9 godzin dziennie za kierownicą. Podczas badań wykorzystano ankietę składającą się z piętnastu pytań. Pogrupowane pytania dotyczyły zakresu wiedzy badanych o dolegliwościach bólowych kręgosłupa na tle przeciążeniowym. Przy obliczaniu wyników użyto pakietu Microsoft Excel.

Wnioski. Bardzo ważne jest informowanie społeczeństwa o znaczeniu aktywności fizycznej, popularyzacja aktywnego wypoczynku i upowszechniania profilaktyki i skutków zmian patologicznych w zakresie bólu pleców przed przeciążeniem.

Key words: spine, low back pain, truck drivers, chronic pain, overload, drivers health, state of knowledge Slowa kluczowe: kręgosłup, dolegliwości bólowe, kierowcy ciężarówek, chroniczny ból, stan wiedzy 


\section{INTRODUCTION}

The spine is a pillar and support for human body. Taking care of the spine just from the day of birth is well known thing among whole population, but is so in practice as well? Back pain definitely is amongst diseases that occur most often in last few decades of the twentieth century. Many of medical researches prove that $60 \%$ to $80 \%$ of our population complain about back pain [1]. There are many causes of that situation; low physical activity, type of performed work, progressive change of life related with huge technical progress which requires from us as little effort as possible [2]. Back pain have become epidemic. This is a global problem, and the worst thing about it is that it still develops in our society. This problem affects more and more people especially at the younger age of our humanity [3].

The human spine is a center of the body. It is designed to fulfill three functions, when working properly [4];

- motor function,

- carrier function- for the head, trunk and extremities,

- protective function- for the spinal cord and nerve roots

In addition to motor function, stabilization function plays a huge role as well. The incorrect stabilization causes incorrect movement pattern, which leads to many overloads in the movement segments, pain syndromes and degenerative changes [5].

Degenerative changes can proceed, providing discopathy, then protrusion of the disc and many other degenerations, which finally can cause the stenosis of spinal canal, compression and irritation on nerve structure $[6,7]$.

Low back pain might occur during both sitting and standing work position. If position is associated with very heavy overload or people are doing the same things all day long, then this is the major reason of pain symptoms in a particular job [2]. An American researches showed that some groups of workers are most vulnerable to overload and back injuries. According to this classification, in standing position work, the first place is going to construction workers, then the miners, while among those working in a sedentary mode, the most vulnerable group are office workers and transport workers.

Although the seating position does not require a lot of energy, the long-term performance of work in the incorrect position leads to an overload of the static structures of the spine [8]. McKenzie Institute in the United States conducted a study which shows that the incidence of back pain did not differ between people easily and hard-working, while the increased number of pain occurs in truck drivers [9].

Among occupational risk factors conductive to overload the spine of working in a sedentery mode, including truck drivers are mentioned [10]: static load due to immobilization, dynamics load due to driving, whole body vibration, bad ergonomic of the seat in the car, temperature changes, chronic stress which increases muscles tonus.

Knowledge of prevention should be known to the same extent, irrespective of the work performed. 'Prevention is better than cure', so that is why the treatment of various symptoms of the spine should be done on many levels [11]. The mere adherence to the principles of ergonomics and spare-time may protect against excessive overload the spine, and does not require much effort, most only develop certain habits.

The aim of study was to assess the state of knowledge in the field of truck drivers back pain against the overload, the prevention and consequences of pathological changes. Moreover, the aim was to answer the following research questions:

1. Is pain of the spine in the profession of truck driver a frequent problem?

2. Are subjects diagnosed with back pain against the overload aware of how to deal with them or who to turn to in order to cover the treatment?

3. Do the respondents know how to prevent back pain disorders?

\section{MATERIAL AND METHODS}

Study group consisted of 120 randomly selected truck drivers, male, working in transport companies in Lower Silesia, dealing mainly with international transport. The age of respondents ranged 25-45 years (mean age was 37.6 years). All respondents spend behind the wheel at least 9 hours a day (two shifts of 4.5-hour, 45 minute break in between).

The study used an own questionnaire, composed of fifteen, grouped questions relating to the state of knowledge of respondents about low back pain against the overload, information on seniority, questions about succession back pain prevalence, type of pain, duration 
of pain at the time of occurrence, the time from when the pain occurs and the frequency of its occurrence in relation to days, weeks, months. Then questions relating to the occurrence of pain during the working day, the difficulty of working activities by back problems, opportunities and ways to cope with pain while driving or during a forced break, by suitable exercises at standstill or accepting certain items during driving. Last questions were about consequences of not treating spine problems, as well as whether the respondent was ever subjected to treatment in this regard, the procedure in case of back pain, need for treatment of any ailment, the type of treatment that respondents would propose in case of feeling pain, knowledge of the causes of the problems and the possible use of the instructions given by a specialist if any have been granted. Surveys were distributed directly to the examined or their superiors by doing research along with a detailed explanation of the research and the questions. Permission to conduct research in any location and from the driver was obtained.

Results were used to show the percentages and average. Calculations were performed in Microsoft Excel.

\section{RESULTS}

Low back pain occurred in more than a half of the respondents $(62.50 \%)$. Difference in the incidence of pain is high, since only $12.50 \%$ of the respondents do not feel pain ailment. Percentage on the frequency of pain for drivers are illustrated in Figure 1.

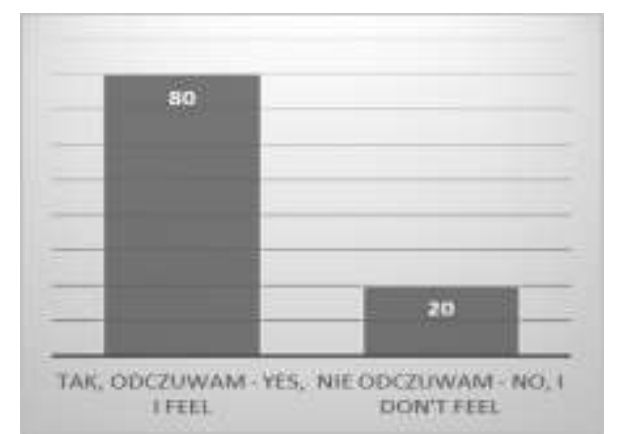

Fig. 1. Occurence of pain for drivers (\%)

Ryc. 1. Częstość występowania dolegliwości bólowych wśród kierowców (\%)

The diagnosis is very important to determine the type of pain. On the question of the nature and type of pain less than a half of the respondents described the kind of pain as a centrally located $(45.83 \%)$, a third of respondents described the pain as radiating to the lower $\operatorname{limb}(31.67 \%)$.

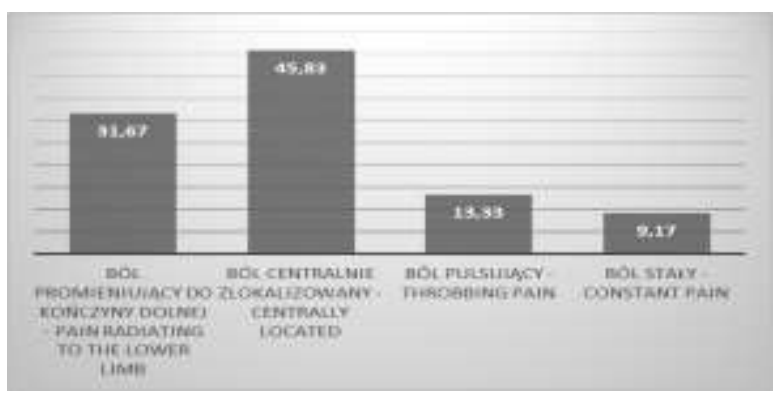

Fig. 2. Type of the pain felt by respondents (\%)

Ryc. 2. Rodzaj bólu odczuwany przez badanych (\%)

When analyzing the entire group of respondents in terms of time in which respondents feel pain, 56 patients $(46.67 \%)$ answered that the pain lasts from a few to several minutes. Almost one quarter of respondents $(24.17 \%)$ feel the pain for a few hours. In relation to the duration of time in which the respondents feel pain, most common response was several years which represents $63.33 \%$ of all responses. The frequency of the disease in a group of patients is diverse. A large number of respondents felt the pain more than once a week. Drivers at work are forced to take breaks and change positions (52.50\%). The most effective analgesic position according to them is the erect position (60\%). Every fifth respondent stated that the pain in the job is annoying and must be supported drugs. For $61.54 \%$ of subjects changing the position or physical activity practiced after work is the best way to stop the pain. Another way to deal with the pain of the drivers are analgesics $(32.50 \%)$. A very small number of respondents $(9.17 \%)$ would choose a consultation with a specialist as another way to cope with pain (fig. 3).

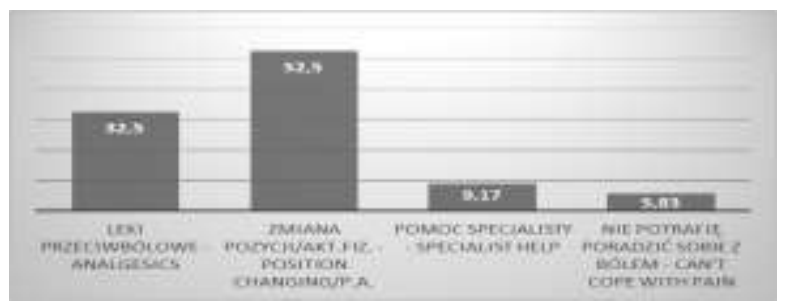

Fig. 3. Ways to cope with pain (\%)

Ryc. 3. Sposoby radzenia sobie z bólem (\%)

Consciousness of the dangers related to lack of treatment of painful ailments among drivers is low because half of the respondents do not think about the consequences of lack of treatment. On the basis of the 
survey it can be seen that a half of the respondents had never been subjected to treatment. Despite this, up to $50 \%$ of respondents believe that the process of treating back pain is necessary. However, being aware of that is not in accordance with theoretical knowledge, because half of respondents did not know the way of the formation of pain. If a patient is faced with the choice specialist, less than half of them $(45 \%)$ go directly to the doctor, consistently adhering to its recommendations $(53.33 \%)$, while one-fifth of respondents (21.67\%) go to the physiotherapist (fig. 4).

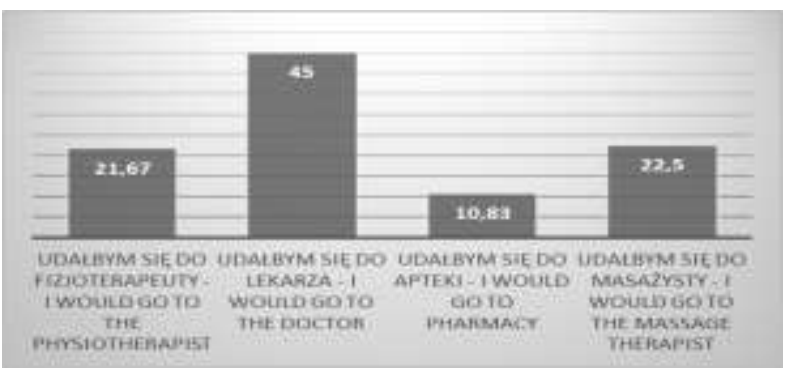

Fig. 4. The choice of treatment in the case of feeling pain (\%) Ryc. 4. Wybór rodzaju leczenia $w$ razie wystepowania dolegliwości bólowych (\%)

Pain, as in any profession also makes it difficult for drivers to work. The survey shows that pain ailments are quite tiring and require drivers to take breaks, as well as assisting the analgesics.

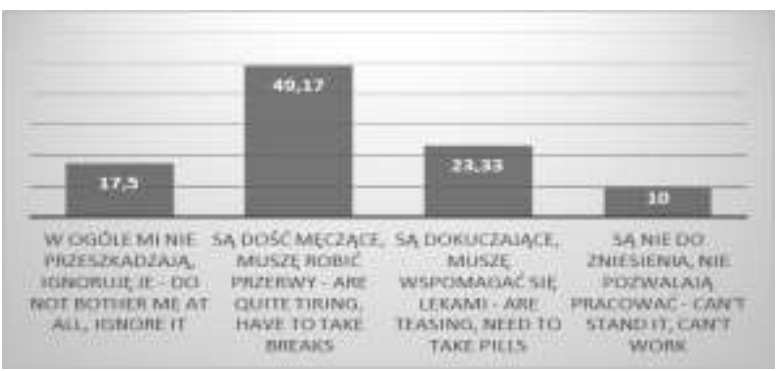

Fig. 5. To what extent have back pain difficult work? (\%) Ryc. 5. Stopień utrudnienia pracy przez dolegliwości bólowe (\%)

\section{DISCUSSION}

Pain in the lumbar spine against the overload is a problem that majority of people working in the profession of the driver faces, as showed by the results of this research, as well as other authors [7]. This is due primarily due to the working conditions; continuous exposure to whole body vibration $[12,13$, 14], work-related stress situations on the road, improperly fitting seat height, badly shaped backrest, the incorrect conditions of hygiene at work and the need to sleep in the cab of a truck are the main factors giving as a result of discomfort during labor, which affects the spine in a number of pathologies that cause pain [15]. This causes an irritation of the soft tissues as well as bone and periosteum, which leads to increased muscle tonus, resulting in stimulation of trigger points [16,17]. Almost every second surveyed driver feels centrally located pain and over $30 \%$ of respondents feel the pain radiating to the lower limb, which also confirms the findings of the other authors [7]. Due to the large number of causes of pain, undoubtedly the diagnosis is always very difficult. In $90 \%$ of cases the cause of the pain are mechanical factors that arise mostly by the static or dynamic overload of the spine. The rest of less than $10 \%$ are organic changes in soft tissues [18]. A sedentary lifestyle and the amount of time that drivers spend in a seated position have a significant impact on the formation of painful, so we have to put a lot of emphasis on the prevention of back pain. Knowledge and awareness of people about the risks and consequences of the incidence of pain syndromes should be deepened [19].

Pain is present in most subjects for several years (63.33\% of respondents), which is a very negative factor for the future, despite the non-advanced age of the patients, which was in the range of 25-45 years. According to a study conducted in Poland, almost $70 \%$ felt the pain associated with ailments of the lumbar spine at least once, which is also confirmed by this research. Pain in the lumbar spine are not a single problem but a problem which, if is misdiagnosed, becomes a chronic problem [18, 20, 21].

As demonstrated in the studies of bus drivers [22], a very large impact on the quality and productivity at work is also the amount of stress that the drivers have to deal with while driving, which is also reflected in truck drivers, due to the high difficulty of driving a truck, impediments on the road as well as the inappropriateness of most of the roads for a comfortable drive such a vehicle.

Recent European research on diseases of musculoskeletal showed that almost $11-47 \%$ percent of people working in the European Union complains of back pain, while 3-30\% complain of pains in the lower limbs which probably may have its reason in the dysfunction of the spine. It is estimated that nearly 44 million people suffer from low back pain [23].

Coping with pain is also a very important issue. If it already comes to incidents of spine, a little over $30 \%$ of respondents choose pharmaceuticals, every second 
$(52.50 \%)$ copes with the pain by changing positions. Most commonly chosen is the erect position (60\%), which may require a break from driving. Flexion position is chosen by one third of the respondent in case of pain, which may also suggest differences in pathology at the level of specific segments of the spine. Drivers are so preoccupied with work that very rarely decide to causal treatment of spine pain, staying in the realm of symptomatic treatment, by changing the position in the automatic way or taking pills, which does not solve the problem, but only masks it. Despite the fact that the majority of respondents $(55 \%)$ declare knowledge of the causes of back pain against the overload, they are not able to support their knowledge with an example. An important problem in the effectiveness of the prevention is the lack of knowledge and awareness of the types of help available. The respondents do not fully know what kind of help they can get from a doctor, physiotherapist or a massage therapist.

Lengthen the average years of life, everyone wants to live better and longer, but to be able to do so properly, you need to follow certain rules. The first of them is to restore the body, what has been taken from it-motion.

\section{CONCLUSIONS}

1. Low back pain in the profession of truck drivers is a common problem and occurs in more than a half of the respondents.

2. The respondents diagnosed with low back pain know who to ask for help in the first line, but there is a lack of consistency in applying for the advice of a specialist.

3. The respondents have little knowledge of the principles of prevention of back pain.

4. There are still not enough information about possible consequences of disregarding back pain.

It is necessary to inform the public about the importance of physical activity, the popularization of active leisure, the dissemination of prevention and consequences of pathological changes in the field of back pain against the overload.

\section{REFERENCES}

1. Tomaszewski W.: Bóle kręgosłupa-plaga XXI wieku. Dbam o kręgosłup.pl.
2. Chomicki Ł., Socha-Masztafiak M., Wpływ charakteru pracy na dolegliwości bólowe kręgosłupa. Rehabilitacja w Praktyce 2014, nr 3, s. 56-57.

3. Klimaszewska K., Krajewska-Kułak E., Kondzior D., Kowalczuk K., Jankowiak B., Jakość życia pacjentów z zespołami bólowymi odcinka lędźwiowego kręgosłupa; Problemy Pielęgniarstwa 2011; 19(1): 47-54.

4. Ignaszewska- Kuhbauch J., Kręgosłup- dlaczego boli? ; Body Life 2000, nr 1, s. 32-35.

5. Stodolny J., Stodolna- Tukendorf J., Profilaktyka powstawania zaburzeń przeciążeniowych w układach ruchowo- stabilizacyjnych kręgosłupa i innych elementach narządu ruchu; Kwart. Ortop. 2009,3, s. 299-308.

6. Gałuszka G., Gałuszka R., Rola prewencji wtórnej w zapobieganiu nawrotom dolegliwości bólowych lędźwiowo- krzyżowego odcinka kręgosłupa wynikających z zespołu przeciążeniowego; Kwart. Ortop. 2005, 3, s. 206-208.

7. Depa A., Drużbicki M., Ocena częstości występowania zespołów bólowych lędźwiowego odcinka kręgosłupa w zależności od charakteru wykonywanej pracy; Przegląd medyczny Uniwersytetu Rzeszowskiego 2008, 1, 34-41.

8. Kamińska J., Liu D.:Dolegliwości kręgosłupa, przyczyny i sposoby ochrony; Bezpieczeństwo Pracy, 4/200, s. 16-17.

9. Janusz M., Ridan T., Kilar J. Z., Szczygieł A., Fotel kierowcy, pasażera i fotel inwalidzki jako miejsce aktywności życiowej zdrowych i niepełnosprawnych; Rozwój Środków Lokomocji dla Osób Niepełnosprawnych [materiały konferencyjne], Przedsiębiorstwo Konstrukcyjno- Badawcze „PROMO”, Kraków 1997.

10. Zagrożenia zdrowia kierowców pojazdów silnikowych związane ze szkodliwymi i uciążliwymi warunkami środowiska pracy; Materiały na posiedzenie Rady Ochrony Pracy, Instytut Medycyny Pracy im. Prof. J. Nofera.

11. Dziak A., Komentarz prof. dr Hab. Med. Artura Dziaka do „Zaleceń stosowania fizjoterapii u pacjentów $\mathrm{z}$ bólami krzyża” wydanych przez Holenderskie Królweskie Towarzystwo Fizjoterapii, Rehab. Med. 2004, 8, 28-30.

12. Bovenzi M., A longitudinal study of low back pain and daily vibration exposure in professional drivers; Industrial Health 2010, 48, 584-595.

13. Tiemessen IJ, Hulshof CT , Frings-Dresen MH. Low back pain in drivers exposed to whole-body vibration: analysis of dose-response pattern; Occup Environ Med. 2008 Oct;65(10):667-7.

14. Robb MJ., Mansfield NJ., Self-reported usculosceletal problems amongst professional truck drivers; Ergonomics. 2007 Jun;50(6):814-27.

15. Bovenzi M., Metrics of Whole-Body Vibration and exposure-response relationship for low back pain in professional drivers: a prospective cohort study; Int Arch Occup Environ Health. 2009 Jul;82(7):893-917. 
16. Słobodzian J., Rakowski A.: Terapia manualna w zespołach bólowych kręgosłupa lędźwiowo krzyżowego, Centrum Terapii Manualnej, Poznań 2001.

17. Kwolek A., Korab D., Majka M.: Rehabilitacja w zespołach bólowych dolnego odcinka kręgosłupa zasady postępowania, Postępy Rehabilitacji, Warszawa 2004, 18, 3, 27-31.

18. Grzegorczyk J., Kwolek A.: Współczesne poglądy na temat rehabilitacji w bólach krzyża, Przegląd Medyczny Uniwersytetu Rzeszowskiego, Rzeszów 2005, 2, 194 200.

19. Leszek Solecki Bóle pleców w dolnej czesci kręgosłupa wśród rolników eksponowanych na wibracje ogólna przegląd pismiennictwa, Medycyna Pracy 2011; 62(2):187-202.

20. Pop T., Przysada G., Świder B.: Stopień niepełnosprawności personelu medycznego mierzony kwestionariuszem Oswestry, Przegląd Medyczny Uniwersytetu Rzeszowskiego, Rzeszów 2008, 2, 135141.

21. Skrzyńska A., Skrzyńska J., Tkaczyk K., Profilaktyka zespołów bólowych $\mathrm{w}$ pozycji siedzącej $\mathrm{w}$ odcinku lędźwiowo -krzyżowym ISSN 2082-1107, 2011, Nr 4 , s. $71-80$.
22. Alperovitch-Najenson D., Santo Y., Masharawi Y., Katz-Leurer M., Ushaew D., Kalichmann L., Low back pain among professional bus drivers: Ergonomic and Occupational-Psychosocial Risk Factors; IMAJ; vol. 12; January 2010.

23. European Agency for Safety and Health at Work: European Risk Observatory Report. Work-related musculoskeletal disorders in the EU. Agency, Luxembourg 2010.

Address for correspondence: e-mail: katedra.fdnr@awf.wroc.pl 71-347-30-76

al. I. J. Paderewskiego 35

51-612 Wrocław

Received: 1.09.2014

Accepted for publication: 4.11.2014 